\title{
SUPERCRITICAL GREEN TECHNOLOGIES FOR OBTAINING GINSENOSIDES FROM FAR-EASTERN WILD GINSENG PANAX GINSENG MEYER USING SFE FOR APPLYING IN DRUG, FOOD AND COSMETIC INDUSTRIES
}

\author{
MAYYA P. RAZGONOVA ${ }^{1}$, TATIANA K. KALENIK ${ }^{2}$, VALERIY V.VESELOV ${ }^{3}$, ALEXANDER M. \\ ZAKHARENKO ${ }^{1}$, ALI TAGHIZADEHGHALEHJOUGHI ${ }^{4}$, VLAD VUȚA ${ }^{5}$, FLORICA \\ BĂRBUCEANU ${ }^{5}$, BORIS N. IZOTOV ${ }^{6}$, ANTONIOS K. STRATIDAKIS ${ }^{7}$, ARISTIDIS M. \\ TSATSAKIS ${ }^{1,3,7^{*}}$, KIRILL S. GOLOKHVAST ${ }^{1,8^{*}}$ \\ ${ }^{I}$ Far Eastern Federal University, Sukhanova Street, 8, Vladivostok 690950, Russian Federation \\ ${ }^{2}$ Biomedical School, Far-Eastern Federal University, Vladivostok, Russia \\ ${ }^{3}$ Center of Bioanalytical Investigation and Molecular Design, I.M. Sechenov First Moscow State Medical University, \\ Moscow, Russia \\ ${ }^{4}$ Department of Pharmacology, Faculty of Medicine, Ataturk University, 25100 Erzurum, Turkey \\ ${ }^{5}$ Institute for Diagnosis and Animal Health, 63 Dr. Staicovici Street, 050557, Bucharest, Romania \\ ${ }^{6}$ Department of Analytical Toxicology, Pharmaceutical Chemistry and Pharmacognosy, Sechenov University, 119991 \\ Moscow, Russia \\ ${ }^{7}$ Laboratory of Toxicology, School of Medicine, University of Crete, Heraklion 71003, Greece \\ ${ }^{8}$ Pacific Geographical Institute FEB RAS, 7 Radio street, Vladivostok, 690014, Russian Federation
}

*corresponding author: golokhvast.ks@dvfu.ru

Manuscript received: September 2018

\begin{abstract}
This study focuses on the effect of the modifier, pressure and temperature on the yield of extractable materials on the method of supercritical fluid $\mathrm{CO}_{2}$ extraction of the root of Far-Eastern wild Panax ginseng Meyer. The amounts of biologically active substances (ginsenosides) obtained with the use of small fractions of the modifier are very small, in contrast to large fractions of the modifier used in the experiment. Several experimental conditions were investigated: variations of pressure levels within the range of 200-400 bar, and ethanol percentages from 2 to $5 \%$ in the liquid phase at a temperature within the range of $31-70^{\circ} \mathrm{C}$.During extraction process with variations in levels of pressure, temperature and amount of modifier, it was found that the presence of the modifier in the extracted system had a significant effect on the amount of extracted ginsenosides. The experimental procedures showed that the main factors that influence the result of ginseng extraction are the density of carbon dioxide, the diffusion coefficient of ginseng oil in carbon dioxide and the volatility of ginseng oil. A direct dependence of the yield of the extract on the amount of modifier was found. High-performance liquid chromatography of all extracts was performed and the quantitative content of ginsenosides in the obtained analytes was established.
\end{abstract}

\section{Rezumat}

Studiul a urmărit efectul unor parametrii fizici și chimici (substanțe chimice adăugate în sistem, variația presiunii şi a temperaturii) asupra randamentului procesului de extracție a ginsenozidelor, din rădăcini provenite din produsul vegetal Panax ginseng Meyer, provenite din culturi obținute în Orient. Metoda de extracție investigată a fost sistemul de extracție cu fluide supercritice îmbogățit cu $\mathrm{CO}_{2}$. Au fost investigate mai multe condiții experimentale: variații ale nivelelor de presiune în intervalul 200-400 bar și procente etanolice în intervalul 2-15\% în faza lichidă, pentru variații de temperaturi cuprinse între $31-70^{\circ} \mathrm{C}$. În timpul procesului de extracție, dezvoltând variații semnificative ale nivelurilor de presiune, temperatură, precum și a cantității de substanțe chimice adăugate, s-a constatat faptul că prezența acestora din urmă în sistemul extras a avut un efect semnificativ asupra cantitătii de ginsenozide extrase din produsul vegetal. Determinările experimentale au arătat că principalii factori care influențează rezultatul extracției ginsenozidelor sunt: densitatea dioxidului de carbon, coeficientul de difuzie a uleiului de ginseng în dioxidul de carbon, precum şi volatilitatea uleiului de ginseng. De asemenea, s-a constatat o dependență directă a randamentului de extractie cu nivelul concentratiei substantelor chimice adăugate în sistem, în scopul optimizării metodei. Analizele prin cromatografie de lichide de înaltă performanță au stabilit conținutul ginsenozidelor din probele experimentale.

Keywords: carbon dioxide, supercritical extraction, Panax ginseng Meyer, ginsenosides, high performance liquid chromatography

\section{Introduction}

Supercritical fluid extraction (SFE) and supercritical fluid chromatography (SFC) have been used since the late 1970 s for food analysis and the determination of fat content and levels of toxicants in food samples. The use of supercritical fluids for fractionation (Supercritical fluid fractionation, SFF) and/or 
FARMACIA, 2019, Vol. 67, 1

enrichment of certain components in products has been reported since the 1980s [1, 2]. However, commercial SCF extracts contain, in general, all the biologically active components along with inert mixtures of extracted formulations [3, 4].

Currently, supercritical fluid extraction is of special significance in the field of extraction from natural matrices. Supercritical extraction exhibits great advantages over conventional extraction processes [5]; e.g. exposure of a non-toxic solvent (supercritical carbon dioxide) to the extractable substance, reduction in the total extraction time, the possibility of more selective extraction, and a significantly reduced volume of organic co-solvent [6].

Supercritical carbon dioxide $\left(\mathrm{scCO}_{2}\right)$, in particular, is an attractive supercritical solvent due to low critical temperatures of use $\left(30-40^{\circ} \mathrm{C}\right)$, its non-toxicity, and inertness. One of the identified shortcomings of using pure $\mathrm{CO}_{2}$ for extraction is the absence of a pure dipole moment; supercritical $\mathrm{CO}_{2}$ inefficiently extracts materials with higher polarity. Therefore, to overcome this barrier, various polar modifiers are used to increase the overall polarity of the liquid phase during extraction. Studies have shown that modifiers often improve the extraction of solid materials, disrupting the bond between solutes and the plant matrix [7]. The dependence of the extraction temperature and extraction pressure on the mole fraction of $\mathrm{CO}_{2}$ is presented in Table I [8].

Table I

Dependence of temperature and pressure by supercritical extraction on the mole fraction of $\mathrm{CO}_{2}$

\begin{tabular}{|c|c|c|c|}
\hline Mole fraction $\mathrm{CO}_{2}$ & $\begin{array}{c}\text { Extraction } \\
\text { temperature }(K)\end{array}$ & $\begin{array}{c}\text { Extraction } \\
\text { pressure (Bar) }\end{array}$ & $\begin{array}{l}\text { Extraction } \\
\text { mixture }\end{array}$ \\
\hline 0.976 & 307.26 & 73.52 & $\mathrm{CO}_{2}+\mathrm{MeOH}$ \\
\hline 0.971 & 308.12 & 76.63 & $\mathrm{CO}_{2}+\mathrm{MeOH}$ \\
\hline 0.894 & 315.67 & 84.49 & $\mathrm{CO}_{2}+\mathrm{MeOH}$ \\
\hline 0.809 & 328.21 & 103.92 & $\mathrm{CO}_{2}+\mathrm{MeOH}$ \\
\hline 0.775 & 335.19 & 115.56 & $\mathrm{CO}_{2}+\mathrm{MeOH}$ \\
\hline 0.751 & 340.65 & 124.04 & $\mathrm{CO}_{2}+\mathrm{MeOH}$ \\
\hline 0.721 & 342.94 & 127.07 & $\mathrm{CO}_{2}+\mathrm{MeOH}$ \\
\hline 0.696 & 355.65 & 141.68 & $\mathrm{CO}_{2}+\mathrm{MeOH}$ \\
\hline 0.654 & 360.65 & 145.33 & $\mathrm{CO}_{2}+\mathrm{MeOH}$ \\
\hline 0.589 & 388.65 & 163.66 & $\mathrm{CO}_{2}+\mathrm{MeOH}$ \\
\hline 0.492 & 422.32 & 164.15 & $\mathrm{CO}_{2}+\mathrm{MeOH}$ \\
\hline 0.956 & 310.58 & 77.73 & $\mathrm{CO}_{2}+\mathrm{EtOH}$ \\
\hline 0.938 & 318.24 & 86.35 & $\mathrm{CO}_{2}+\mathrm{EtOH}$ \\
\hline 0.863 & 328.36 & 100.89 & $\mathrm{CO}_{2}+\mathrm{EtOH}$ \\
\hline 0.769 & 350.62 & 128.04 & $\mathrm{CO}_{2}+\mathrm{EtOH}$ \\
\hline 0.697 & 377.17 & 146.3 & $\mathrm{CO}_{2}+\mathrm{EtOH}$ \\
\hline 0.646 & 393.08 & 151.54 & $\mathrm{CO}_{2}+\mathrm{EtOH}$ \\
\hline 0.597 & 410.32 & 151.67 & $\mathrm{CO}_{2}+\mathrm{EtOH}$ \\
\hline
\end{tabular}

SFE has been used in the extraction of many natural products, including nimbin from neem seeds [9], antioxidants from coriander seeds [10], $\beta$-carotene from carrots [11] and ginger oleoresin (turpentine) from ginger [12].

Previous research studies have demonstrated the therapeutic uses of plant extracts through the years [13-19]. Far Eastern Panax ginseng Meyer is a perennial plant in the Araliaceae family used for hundreds of years in traditional oriental medicine. The main active components in Panax ginseng are the ginsenosides, which are a group of saponins with a triterpenoid dammarane structure.This medicinal plant grows mainly in Northeast Asia, including Korea. Products from dry ginseng (DG) and red ginseng $(\mathrm{RG})$ are consumed as important functional foods $[20,21]$.

Six ginseng glycosides (A,B,C,D,E,F) were firstly isolated as active components of ginseng in 1957 by the famous Russian scientists Yelyakov G.B. and Brehkman I.I. Based on the properties of the aglycone (part of the glycoside devoid of the carbohydrate radical), they named the glycosides of the protopanaxatriol group 'panaxosides A, B and 
C', and the glycosides of the protopanaxadiol group 'panaxosides D, E and F'. Over time, other members of these groups were isolated, but since places between $\mathrm{C}$ and $\mathrm{D}$ no longer existed, the newly discovered compounds were called ginsenosides and numbers were assigned to them corresponding to their mobility on chromatograms. Their structure was clarified and named ginsenoside by Shibata's Japanese research group [22, 23].

Ginsenosides are the main components considered when determining the quality of ginseng [24, 25]. Ginsenosides in ginsengare active ingredients that deliver a wide range of medicinal effects on health e.g., antitumor, antidiabetic, anti-neurodegenerative and anti-inflammatory actions, improvement of liver function, and maintenance of homeostasis in the body [26-30]. Far Eastern ginseng contains a large amount of various natural useful compounds in addition to ginsenosides: phenolic compounds with antioxidant activity, polyacetylene and sesquiterpene (compounds with demonstrated cytotoxicity to cancer cells). The effect of polysaccharides in ginseng on immune function was also actively studied [31]. The most fully investigated active components of Panax ginseng Meyer, are presented in Table II.

Table II

Structural formulas of ginsenosides from Panax ginseng Meyer

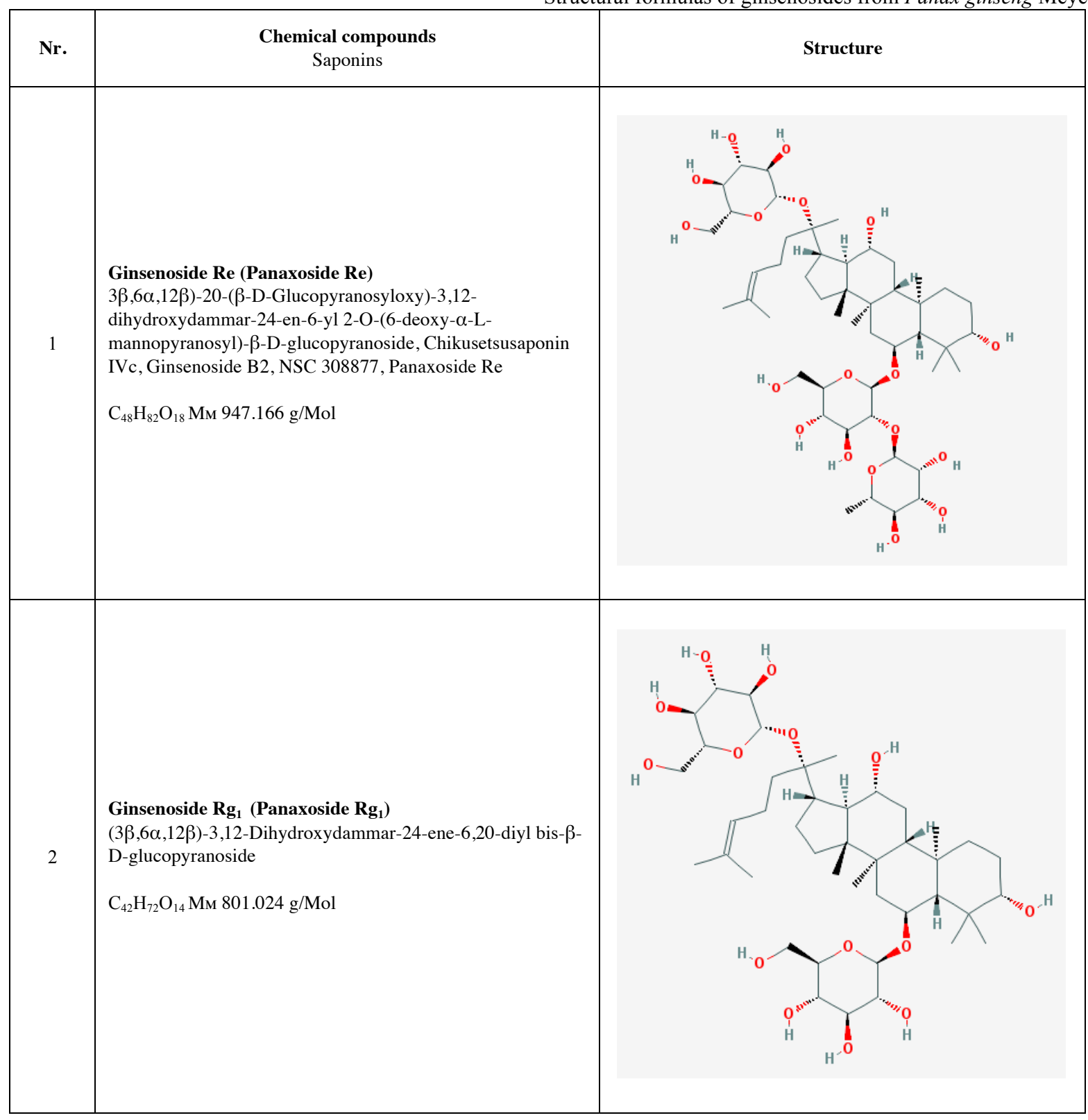


FARMACIA, 2019, Vol. 67, 1

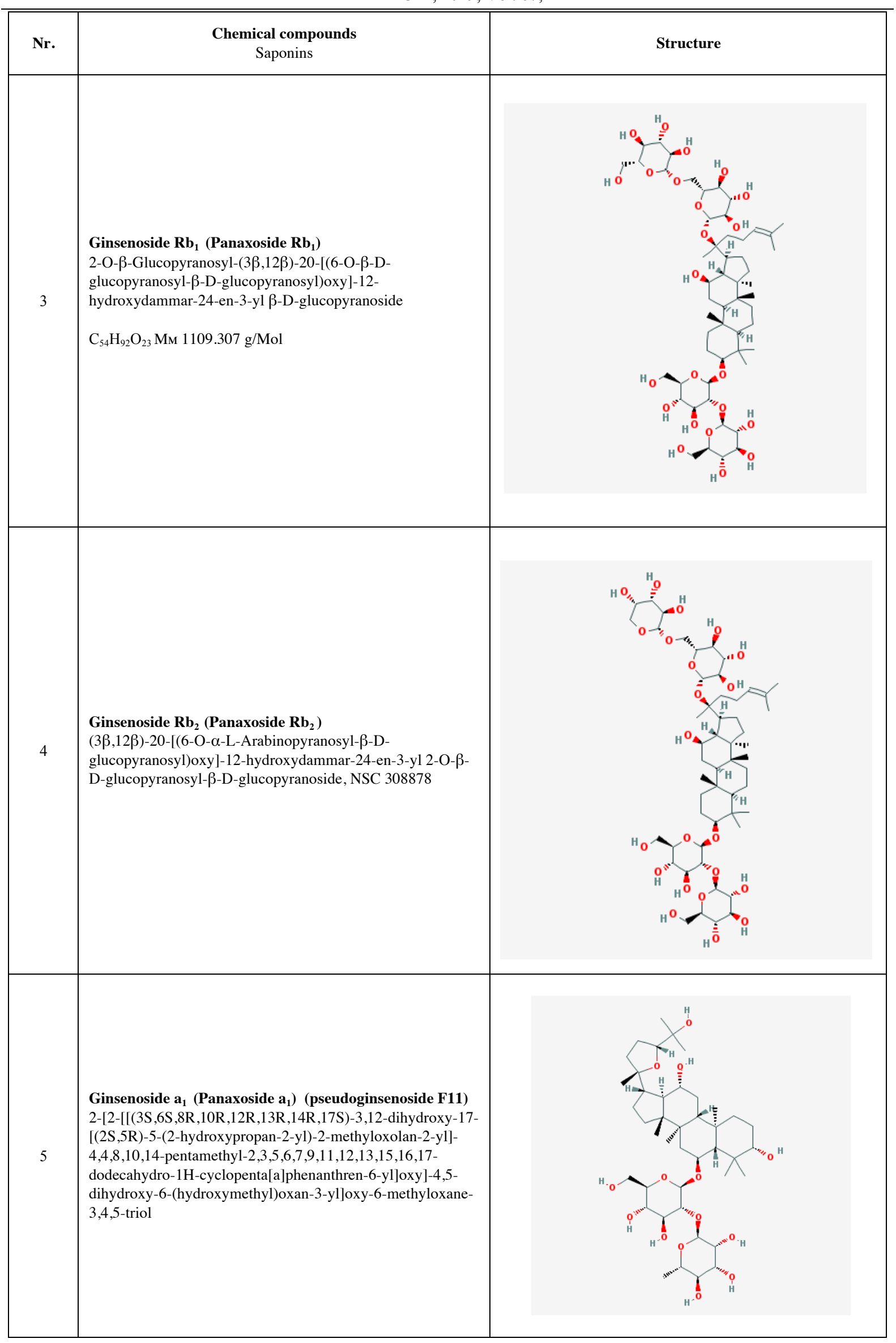


FARMACIA, 2019, Vol. 67, 1

\begin{tabular}{|c|c|c|}
\hline Nr. & $\begin{array}{l}\text { Chemical compounds } \\
\text { Saponins }\end{array}$ & Structure \\
\hline . & 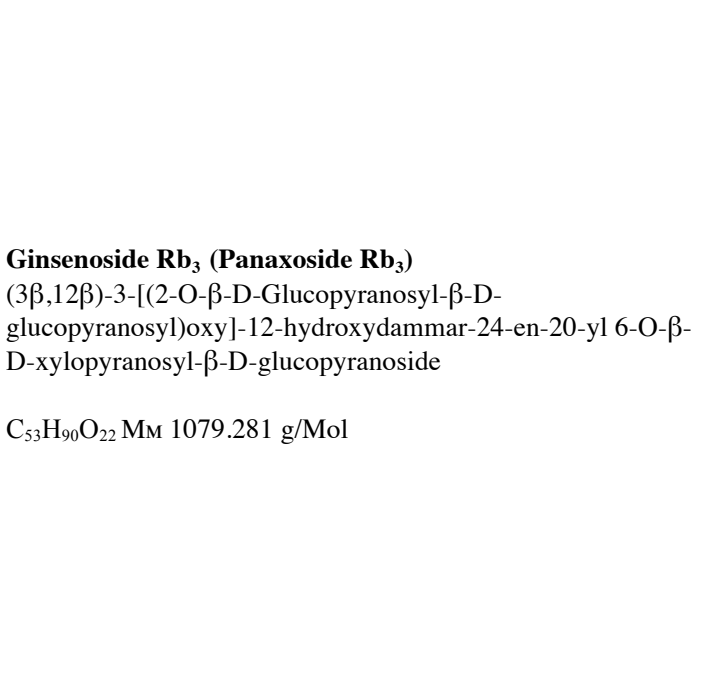 & $\mathrm{H}^{\mathrm{O}}$ \\
\hline
\end{tabular}

The most popular ginsenosides present in Far-Eastern ginseng (Panax ginseng Meyer) and American ginseng (Panax quinquefolium) are neutral ginsenosides, $R b_{1}, R b_{2}, R c, R d, R e$ and $R_{1}$ and malonyl-ginsenosides, $m-\mathrm{Rb}_{1}, \mathrm{~m}-\mathrm{R} \mathrm{b}_{2}, \mathrm{~m}-\mathrm{Rc}$ and $\mathrm{m}-\mathrm{Rd}$. Significant amounts of $\mathrm{Rf}$ are also found in Asian ginseng, but not in American ginseng [32, 33, 34]. Modern research studies are reporting the discovery of new types of ginsenosides and other functional compounds in Panax ginseng Meyer [35, 36].

It should be noted that some ginsenosides compounds and especially malonyl ginsenosides are thermally unstable compounds, breaking down during heat treatment [37]. Thermal degradation of neutral ginsenosides in an aqueous solution under ordinary heating has been extensively studied in many scientific works [38].

However, due to the thermal instability of some ginsenosides, production and quality of extracts from Panax ginseng Meyer depends on the extraction method [37]. Conventional extraction methods for isolating ginsenosides from ginseng include Soxhlet extraction, ultrasonic extraction, and microwave extraction [40].Some conventional extraction methods require a long extraction period and large amounts of solvent, which can lead to the thermal destruction of the target components. The first supercritical extraction applied to Panax ginseng Meyer was by Wang et al., 2001 [41]. In addition, a subsequent filtration and / or concentration step are often required to remove the solid residue [42]. Supercritical fluid extraction (SFE) using $\mathrm{CO}_{2}$ and a polar modifier showed significant advantages in the extraction of medicinal plants [43]. The unique properties of supercritical fluids served as the basis for their application in the extraction of thermo-unstable compounds from natural plant matrices, in particular, Far Eastern Panax ginseng Meyer [44, 45, 46].

\section{Materials and Methods}

Chemicals and Reagents

Wild ginseng (Panax ginseng Meyer) was purchased in Lazovsky district of Primorye, Sikhote-Alin mountain range, Russia. Analytical qualitative solvents, including UN 1648 acetonitrile, methanol, ethanol for supercritical $\mathrm{CO}_{2}$ extraction and chromatography were purchased from PanReac AppliChem, Germany.

Chromatographic analysis was performed on a Shimadzu LC-20 Prominence UFLC liquid chromatograph (Shimadzu Corp., Tokyo, Japan).

The deionized water used in high-performance liquid chromatography was prepared with Siemens Ultra Clear equipment (Siemens, Germany).

The extraction apparatus of supercritical pressure Thar SFC, S.N. 3526551, USA, was used for supercritical $\mathrm{CO}_{2}$ extraction.

Mixed standard solutions of ginsenosides were supplied by FarEastern Federal University in forms of separate sealed $0.5 \mathrm{~mL}$ ampoules. When diluted to appropriate concentrations, solutions of ginsenosides served to establish the retention time and as independent calibration standards. Standards have been retained at $-18^{\circ} \mathrm{C}$.

Extraction of wild Panax ginseng Meyer

A supercritical fluid extraction system was used in supercritical extraction. Carbon dioxide was compressed to the required pressure using a supercritical extraction compressor (Thar SFC, USA). A hot casing string heated the extraction vessel; the temperature was regulated by a thermostat $\left( \pm 1^{\circ} \mathrm{C}\right)$. A metering valve controlled the pressure. Shredded 
ginseng roots $(6.5 \mathrm{~g})$ were wrapped in filter paper, charged to a one litre extractor and extracted with supercritical $\mathrm{CO}_{2}$ compressed to a supercritical state at a liquid flow rate of $250 \mathrm{~g} / \mathrm{min}$. Six SFE extracts were obtained under different pressure conditions $(200,300$ and 400 bar) and temperatures $\left(31-70^{\circ} \mathrm{C}\right)$. Ethanol served as the co-solvent in all cases. The extracts were collected in a separator. The pressure and temperature of the supercritical $\mathrm{CO}_{2}$ were optimized experimentally to achieve the maximum yield of the product during extraction.

HPLC procedure

Separation of samples was performed by high performance liquid chromatography (HPLC) on a Shodex ODP-40 4E column $(250 \mathrm{~mm} \times 4.6 \mathrm{~mm}$, particle size 4 , number of theoretical plates $>17.000$, Shodex, Japan) at room temperature with a double mobile phase consisting of acetonitrile (solvent A) and water (solvent $\mathrm{B}$ ) at a flow rate of $1.0 \mathrm{~mL} \mathrm{~min}$. The gradient elution program was: $0.01-4 \mathrm{~min}, 100 \% \mathrm{~A}$; 4$60 \mathrm{~min}, 100-25 \%$ A; $60-75 \mathrm{~min}, 25-0 \%$ A: control wash $75-120 \mathrm{~min}, 0 \% \mathrm{~A}$. The HPLC analysis was performed with a DAD detector at $230 \mathrm{~nm}$ and 330 nm. A similar technology for isolating ginsenosides was used by Cheng et al. [47].

The content of ginsenosides in supercritical $\mathrm{CO}_{2}$ extracts was analysed using high performance liquid chromatography HPLC. To analyse the compounds, we used a Shimadzu LC-20 Prominence UFLC liquid phase-shift chromatograph with an LCMS-2020 quadrupole LCMA-spectrometer (Japan) equipped with an ultraviolet sensor and a Shodex ODP-40 4E reverse phase column $(250 \mathrm{~mm} \times 4.6 \mathrm{~mm}$, particle size 4 , number of theoretical plates $>17.000$, Shodex, Japan); the control was at $230 \mathrm{~nm}$ and $330 \mathrm{~nm}$. The injection volume was $20 \mu \mathrm{L}$, the temperature of the thermostat was $17^{\circ} \mathrm{C}$, and the flow rate of the liquid was $0.4 \mathrm{~mL} / \mathrm{min}$.

Sample were analysed by an isocratic solvation system, the mobile phase of which was in a 25:75 ratio of the aqueous and acetonitrile solvent. Organic solvent consisted of UN1648 acetonitrile.

\section{Results and Discussion}

Figure 1 shows several chromatograms combined in one graph - successful replicates of the chromatography of a supercritical extract of Panax ginseng Meyer. 43 chromatographic peaks corresponding to compounds of ginsenosides in ginseng were isolated.

This demonstrates the experimental possibility of obtaining the most pure thermo-unstable compounds of drugs from natural matrices, using revolutionary "green" supercritical $\mathrm{CO}_{2}$-extraction.

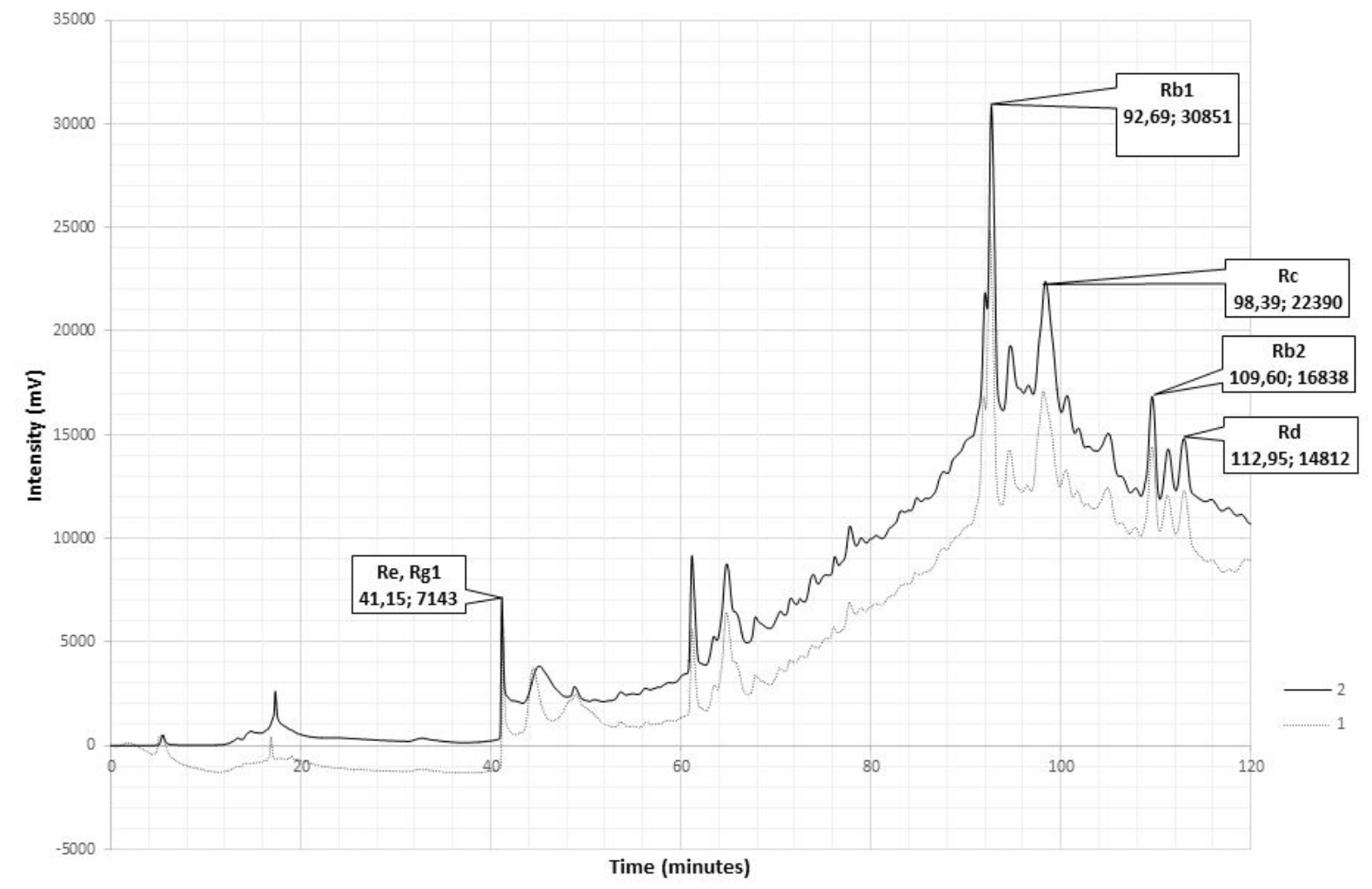

Figure 1

Chromatogram of $\mathrm{CO}_{2}$ extract of Panax ginseng Meyer (breakdown of peaks by maxima of ginsenosides). Gradient elution program: $0.01-4 \mathrm{~min}, 100 \% \mathrm{~A}$; 4-60 $\mathrm{min}, 100-25 \% \mathrm{~A}$; 60-75 $\mathrm{min}, 25-0 \% \mathrm{~A}$ : control wash $75-120 \mathrm{~min} 0 \% \mathrm{~A}$.

DAD detector at $230 \mathrm{~nm}$ 
FARMACIA, 2019, Vol. 67, 1

Lang et al., 2001 [7] reported that extraction enhanced by a modifier, in particular when the modifier directly affects the solid matrix, could have a profound effect on the amount and quality of the extract.

During the extraction process with variations in levels of pressure, temperature and amount of modifier, it was found that the presence of the modifier in the extracted system had a significant effect on the amount of extracted ginsenosides. The solubility of the solute in the supercritical fluid is related to the density of the solvent and the volatility of the solution. In this study, the main factors that influenced the result of ginseng extraction were the density of carbon dioxide, the diffusion coefficient of ginseng oil in carbon dioxide and the volatility of ginseng oil.

The amount of extractable ginsenosides was very small with a low modifier volume (less than $1 \mathrm{~g}$ of ginseng modifier), and so higher amounts of modifier were also studied. Figure 2 presents an orthogonal projection representing a series of successful $\mathrm{CO}_{2}$ extractions of ginseng at various temperatures and pressures. It can be concluded that the most optimized extraction procedure is achieved at a pressure of 400 bar and a temperature of 55$60^{\circ} \mathrm{C}$

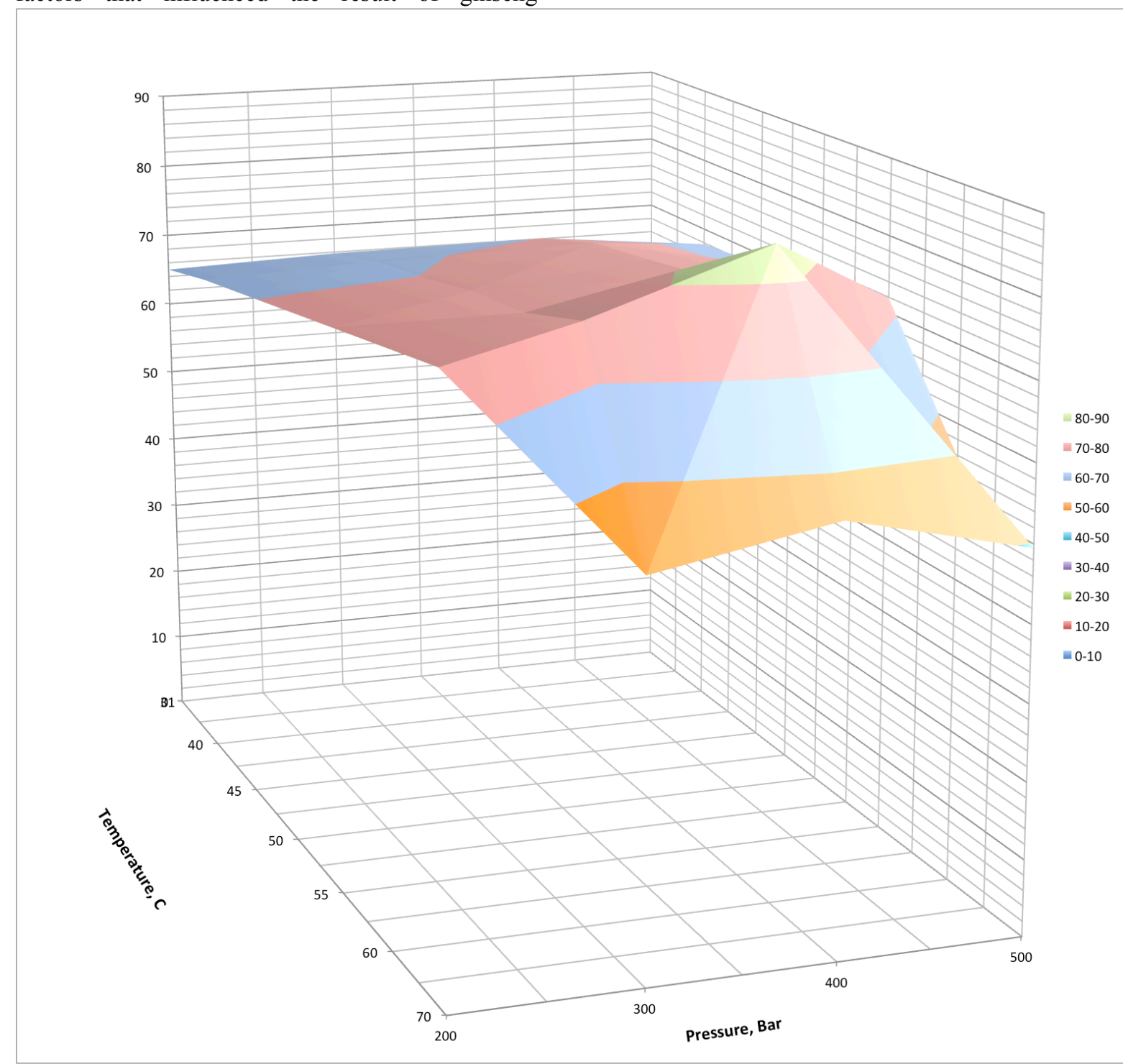

Figure 2

Orthogonal projection representing a series of successful $\mathrm{CO}_{2}$-extractions of Panax ginseng Meyer at various temperatures and pressures.

Using $\mathrm{CO}_{2}$ and EtOH as modifiers, the most interesting experimental conditions were investigated in the pressure range 200-500 bar, the percentage of ethanol from 1.7 to $3.4 \%$ in the liquid phase, at a temperature in the range of $31-70^{\circ} \mathrm{C}$. In particular, Tables III and IV show the total extraction results for ginsenosides at a pressure of 200 bar and an amount of ethanol modifier of $1.7 \%$ and $3.4 \%$, respectively. 
Quantitative yield of six ginsenosides in supercritical $\mathrm{CO}_{2}$ extraction, depending on the extraction pressure. Operation pressure 200 bar, EtOH: $3.4 \%$

\begin{tabular}{|c|c|c|c|c|c|c|c|}
\hline & $\mathbf{R b 1}(\mathbf{m g} / \mathbf{g})$ & $\begin{array}{c}\mathbf{R b 2} \\
(\mathbf{m g} / \mathbf{g})\end{array}$ & $\mathbf{R c}(\mathbf{m g} / \mathbf{g})$ & $\mathbf{R d}(\mathbf{m g} / \mathbf{g})$ & $\mathbf{R e} / \mathbf{R g 1}(\mathbf{m g} / \mathbf{g})$ & $\begin{array}{c}\text { Total } \\
\text { ginsenosides } \\
\text { recovered } \\
\mathbf{( m g / g )}\end{array}$ & $\begin{array}{c}\text { Temperature } \\
\text { at extraction } \\
\text { pressure 200 } \\
\text { bar }\end{array}$ \\
\hline 1 & 34.3 & 1.35 & 4.78 & 7.64 & 17.4 & 65.47 & 31 \\
\hline 2 & 35.3 & 1.01 & 6.12 & 5.88 & 19.1 & 67.41 & 40 \\
\hline 3 & 36.1 & 1.14 & 4.69 & 6.18 & 18.5 & 66.61 & 45 \\
\hline 5 & 36.4 & 0.78 & 5.03 & 7.38 & 18.2 & 67.79 & 50 \\
\hline 6 & 37.4 & 1.25 & 4.57 & 7.04 & 18.4 & 68.66 & 55 \\
\hline 7 & 18.6 & 0.35 & 2.32 & 5.12 & 14.5 & 40.89 & 60 \\
\hline
\end{tabular}

Table IV

Quantitative yield of six ginsenosides in supercritical $\mathrm{CO}_{2}$ extraction, depending on the extraction pressure.

\begin{tabular}{|c|c|c|c|c|c|c|c|}
\hline & Rb1 (mg/g) & $\begin{array}{c}\mathbf{R b 2} \\
(\mathrm{mg} / \mathrm{g})\end{array}$ & $\operatorname{Rc}(\mathrm{mg} / \mathrm{g})$ & Rd (mg/g) & $\operatorname{Re} / \operatorname{Rg} 1$ (mg/g) & $\begin{array}{c}\text { Total } \\
\text { ginsenosides } \\
\text { recovered } \\
(\mathrm{mg} / \mathrm{g})\end{array}$ & $\begin{array}{c}\text { Temperature at } \\
\text { extraction } \\
\text { pressure 200 } \\
\text { bar }\end{array}$ \\
\hline 1 & 35.1 & 1.38 & 4.79 & 7.81 & 18.3 & 67.38 & 31 \\
\hline 2 & 35.5 & 1.04 & 6.17 & 5.9 & 19.7 & 68.31 & 40 \\
\hline 3 & 36.7 & 1.19 & 4.85 & 6.4 & 19.2 & 68.34 & 45 \\
\hline 4 & 37.2 & 0.92 & 5.03 & 7.91 & 19.1 & 70.16 & 50 \\
\hline 5 & 43.1 & 1.28 & 4.67 & 8.03 & 19.4 & 76.48 & 55 \\
\hline 6 & 23.8 & 0.39 & 3.45 & 6.7 & 15.7 & 50.04 & 60 \\
\hline 7 & 23.1 & 0.37 & 2.32 & 5.21 & 14.15 & 45.15 & 70 \\
\hline
\end{tabular}

Figure 3 presents a series of successful experiments on supercritical ginseng extraction with a change in pressure and in proportion of co-solvent EtOH.

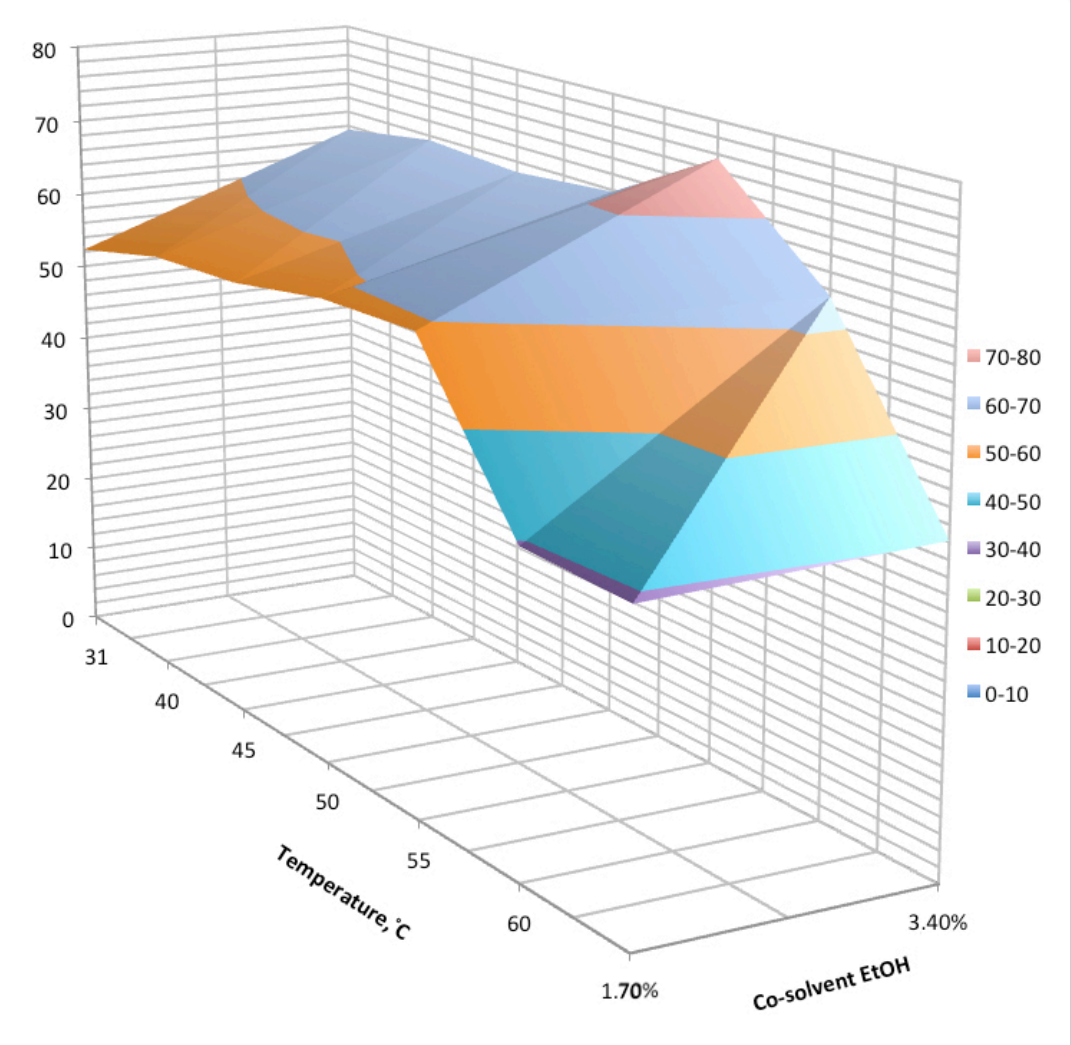

Figure 3

Series of successful experiments of supercritical extraction of Panax ginseng Meyer with a change in pressure and proportion of co-solvent EtOH 
Increase of the concentration of the modifier can result in a large effect on the amount of extraction yield in effective supercritical extraction. Supercritical extraction using $\mathrm{CO}_{2}$ and $\mathrm{EtOH}$ as a modifier is an effective method of extracting biologically active substances, in particular ginsenosides, from ginseng. But it should be noted that during the experiment, quite high amounts of modifier are needed.

The use of ethanol in the conducted experiments showed that it is an effective modifier for SFE while extraction with the ginsenoside modifier was significantly enhanced compared to pure $\mathrm{CO}_{2}$ extraction.

The suggested conclusion that an increased concentration of modifier can have a large effect on the critical temperature of the $\mathrm{CO}_{2}+\mathrm{EtOH}$ extraction mixture was also confirmed. As known, the higher the operating temperature, the greater the density of the liquid. A temperature of $60-65^{\circ} \mathrm{C}$ actually stopped the improvement of extraction kinetics. The effect of higher pressure on the increase in fluid density was further studied in relation to how this affected the extraction of ginsenosides.

Chromatographic analysis of HPLC extraction (Figure 1) revealed six ginsenosides: $R b_{1}, R b_{2}, R c, R d, R e$ and $\mathrm{Rg}_{1}$. Also, four acidic ginsenosides were identified, which are otherwise called malonyl ginsenosides. Malonyl ginsenosides are found in ginseng in significant quantities. However, these ginsenosides are unstable at high temperatures. The absence of significant quantities of malonyl ginsenosides after extraction is consistent with other studies [48, 49], which mention that extraction with methanol for 20 hours in a Soxhlet extractor is sufficient to convert the malonyl ginsenosides to neutral ginsenosides.

Higher-pressure conditions (300 bar and 400 bar) were also studied to see how they increase the density of the liquid (and, accordingly, the solvation force) and to determine how this affected the extraction of ginsenosides. As known, solvation is an important condition for the dissolution of substances and the stability of solutions, suspensions and emulsions, including solutions of biopolymers (proteins, nucleic acids) or bio emulsions (blood plasma, lymph).

\section{Conclusions}

During the extraction process with variations in levels of pressure, temperature and amount of modifier, it was found that the presence of the modifier in the extracted system had a significant effect on the amount of extracted ginsenosides. The experimental procedures showed that the main factors that influence the result of ginseng extraction are the density of carbon dioxide, the diffusion coefficient of ginseng oil in carbon dioxide and the volatility of ginseng oil. Chromatographic analysis of HPLC extraction revealed six ginsenosides: $\mathrm{Rb}_{1}, \mathrm{Rb}_{2}, \mathrm{Rc}, \mathrm{Rd}, \mathrm{Re}$ and
$\mathrm{Rg}_{1}$, while four acidic ginsenosides were also identified.

It can be concluded that the most optimized extraction procedure is achieved at a pressure of 400 bar and a temperature of $55-60^{\circ} \mathrm{C}$.

Supercritical extraction using $\mathrm{CO}_{2}$ and EtOH as modifiers is an effective method of extracting biologically active substances as ginsenosides, while the efficiency of ethanol for extracting such active substances proved to be greater than using pure $\mathrm{CO}_{2}$. On the contrary, it should be noted that during the experiment, high amounts of modifier are needed.

The suggested conclusion that an increased concentration of modifier can have a large effect on the critical temperature of the $\mathrm{CO}_{2}+\mathrm{EtOH}$ extraction mixture was also confirmed.

\section{References}

1. Brondz I, Supercritical fluids: supercritical fluid extraction (SFE) and supercritical fluid chromatography. Am J Anal Chem., 2012; 3(12A): 867-869.

2. Herrero M, Mendiola JA, Cifuentes A, Ibanez E, Supercritical fluid extraction: recent advances and applications. J Chromatogr A, 2009; 1217: 24952511.

3. King JW, Supercritical fluid processing of nutritionally functional lipids. In Healthful Lipids, ed. CC Akoh, O-M Lai., 2005, 99-126, Champaign, IL, AOCS Press

4. Brunner G, Applications of supercritical fluids. Annu Rev Chem Biomol Eng., 2010; 1: 321-342.

5. King J, Modern supercritical fluid technology for food applications. Annu Rev Food Sci Technol., 2014; 5: 215-238.

6. Taylor, Supercritical Fluid Extraction, John Wiley \& Sons, Inc., 1996, Toronto.

7. Lang Q, Wai CM, Supercritical fluid extraction in herbal and natural product studies - a practical review, Talanta, 2001; 53: 771-782.

8. Yeo SD, Park SJ, Kim JW, Kim JC, Critical Properties of Carbon Dioxide + Methanol, + Ethanol, +1-Propanol, and + 1-Butanol. J Chem Eng., 2000; 45: 932-935.

9. Tonthubthimthong P, Douglas PL, Douglas S, Luewisutthichat W, Teppaitoon W, Pengsopa L, Extraction of nimbin from neem seeds using supercritical $\mathrm{CO}_{2}$ and a supercritical $\mathrm{CO}_{2}+$ methanol mixture. J Supercrit Fluids., 2004; 30 : 287-301.

10. Yepez B, Espinosa M, Lopez S, Bolanos G, Producing antioxidant fractions from herbaceous matrices by supercritical fluid extraction. Fluid Phase Equilib., 2000; 194: 879-884.

11. Subra P, Castellani S, Jestin P, Aoufi A, Extraction of $\beta$-carotene with supercritical fluids: experiments and modelling. J Supercrit Fluids, 1998; 12(1998): 261-269.

12. Zancan KC, Marques MOM, Petenate AJ, Meireles MAA, Extraction of ginger (Zingiber officinale Roscoe) oleoresin with $\mathrm{CO}_{2}$ and co-solvents: a 
study of antioxidant action of extracts. $J$ Supercrit Fluids, 2002; 24(2002): 57-76.

13. Veskoukis AS, Tsatsakis AM, Kouretas D, Dietary oxidative stress and antioxidant defense with an emphasis on plant extract administration. Cell Stress Chaperone, 2012; 17(1): 11-21.

14. Stagos D, Amoutzias GD, Matakos A, Spyrou A, Tsatsakis AM, Kouretas D, Chemoprevention of liver cancer by plant polyphenols. Food Chem Toxicol, 2012; 50(6): 2155-2170.

15. Olaru OT, Venables L, Van De Venter $M$, Nitulescu GM, Margina D, Spandidos DA, Tsatsakis AM, Anticancer potential of selected Fallopia Adans species. Oncol Lett., 2015; 10(3): 1323-1332.

16. Skenderidis P, Kerasioti E, Karkanta E, Stagos D, Kouretas D, Petrotos K, Hadjichristodoulou C, Tsakalof A, Assessment of the antioxidant and antimutagenic activity of extracts from goji berry of Greek cultivation. Toxicol Rep., 2018; 5: 251-257.

17. Alkan EE, Celik I, The therapeutics effects and toxic risk of Heracleumpersicum Desf. extract on streptozotocin-induced diabetic rats. Toxicol Rep., 2018; 5: 919-926.

18. Sani TA, Mohammadpour E, Mohammadi A, Memariani T, Yazdi MV, Rezaee R, Calina D, Docea AO, Goumenou M, Etemad L, Shahsavand $\mathrm{S}$, Cytotoxic and apoptogenic properties of dracocephalumkotschyi aerial part different fractions on calu- 6 and mehr-80 lung cancer cell lines. Farmacia, 2017; 65(2): 189-199.

19. Fenga C, Costa C, Caruso E, Raffa L, Alibrando C, Gangemi S, Docea AO, Tsatsakis AM, Current evidence on the protective effect of dietary polyphenols on breast cancer. Farmacia, 2016; 64(1): 1-12.

20. Kim BH, Lee YG, Park TY, Kim HB, Rhee MH, Cho JY, Ginsenoside Rp1, a ginsenoside derivative, blocks lipopolysaccharide-induced interleukin-1 beta production via suppression of the NFkappaB pathway. Planta Medica, 2009; 75(4): 321-326.

21. Sun B, Xiao J, Sun XB, Wu Y, Notoginsenoside R1 attenuates cardiac dysfunction in endotoxemic mice: an insight into oestrogen receptor activation and PI3K/Akt signaling. $B r \quad J$ Pharmacol., 2013;168(7): 1758-1770.

22. Shibata S, Tanaka O, Ando T, Sado M, Tsushima $\mathrm{S}$, Ohsawa T, Chemical studies on oriental plants drugs. Protopanaxadiol, a genuine sapogenin of ginseng saponins. Chem farm bull(Tokyo), 1966; 14(6): 595-600.

23. Yamaguchi H, Kasai R, Matsuura H, Tanaka O, Fuwa TY, High-performance liquid chromatographic analysis of acidic saponins of ginseng and related plants. Chem farm bill (Tokyo), 1988; 36(9): 34693473.

24. Brown PN, Determination of ginsenoside content in Asian and North American ginseng raw materials and finished products by high-performance liquid chromatography: single-laboratory validation. $J$ AOAC Int., 2011; 94(5): 1391-1399.

25. Quan $\mathrm{C}$, Li S, Tian $\mathrm{S}, \mathrm{Xu} \mathrm{H}$, Lin $\mathrm{A}, \mathrm{Gu} \mathrm{L}$, Supercritical fluid extraction and clean-up of organochlorine pesticides in ginseng. $J$ Supercrit Fluids, 2004; 31(2): 149-157.

26. Lacaille-Dubois MA, Wagner HA, Review of the biological and pharmacological activities of saponins. Phytomedicine, 1996; 2(4): 363-386.

27. Bachran C, Bachran S, Sutherland M, Bachran D, Fuchs H, Saponins in tumor therapy. Mini Rev Med Chem, 2008; 8: 575-584.

28. Xie JT, Mchendale S, Yuan CS, Ginseng and diabetes. Am J Chin Med., 2005; 33: 397-404.

29. Cho IH, Effects of Panax ginseng in neurodegenerative diseases. J Ginseng Res, 2012; 36(4): 342-353

30. Sakato T, Etou H, Fujimoto K, Ookuma K, Hayachi T, Arichi S, Central effects of ginsenosides on the feeding behavior and response to stress in rats. Korean J Ginseng Sci., 1987; 11: 164-172.

31. Park JD, Recent studies on the chemical constituents of Korean Ginseng (Panax ginseng C.A. Meyer). Korea J Ginseng Sci., 1996; 20: 389415.

32. Chuang WC, Sheu SJ, Determination of ginsenosides in crude extracts by high-performance liquid chromatography. $J$ Chromatogr A, 1994; 685: 243-251.

33. Ko SR, Choi KJ, Kim SC, Han KW, Content and composition of saponin compounds of Panaxspecies. Korean J Ginseng Sci., 1995; 19: 254-259.

34. Kochkin DV, Galishev BA, Glagoleva ES, Titova MV, Nosov AM, Rare triterpene glycoside of ginseng (ginsenoside malonyl-RG1 detected in plant cell suspension culture of Panax japonicus var. repens. Russian journal of plant physiology, 2017; 64(4): 649-656.

35. Park IH, Kim NY, Han SB, Kim JM, Kwon SW, Kim HJ, Park MK, Park JH, Three new dammarane glycosides from heat processed ginseng. Arch Pharm Res, 2002; 25(4): 428-432.

36. Nicol RW, Traquair JA, Bernards MA, Ginsenosides as host resistance factors in American ginseng (Panax quinquefolius). Canadian Journal of Botany, 2002; 80(5): 557-562.

37. Samukawa K, Yamashita H, Matsuda H, Kubo M, Simultaneousanalysis of ginsenosides in various ginseng radix by HPLC, Yakugaku Zasshi, 1995; 115: 241-249

38. Lee S, Kim S, Kim K, Stability of red ginseng saponin in aqueous solution. J Korean Pharm Sci., 1994; 24: 227-231.

39. Wood JA, Bernards MA, Wan-kei W, Charpentier PA, Extraction of ginsenosides from North American ginseng using modified supercritical carbon dioxide. J Supercrit Fluids, 2006; 39: 4047.

40. Kwon JH, Belanger JM, Pare J, Yaylayan VA, Application of the microwave-assisted process (MAPTM) to the fast extraction of ginseng saponins. Food Research International, 2003; 36: 491-498.

41. Wang HC, Chen CR, Chang CJ, Carbon dioxide extraction of ginseng root hair oil and ginsenosides. Food chemistry, 2001; 72(4): 505-509. 
42. Wang L, Weller CL, Recent advances in extraction of nutraceuticals from plants. Trends in Food Science \& Technology, 2006; 17: 300-312.

43. Reverchon E, De Marco I, Supercritical fluid extraction and fractionation of natural matter. $J$ Supercrit Fluids, 2006; 38: 146-166.

44. Wu Y, Xia ZY, Dou J, Zhang L, Xu JJ, Zhao B, Lei $\mathrm{S}$, Liu HM, Protective effect of ginsenoside Rb1 against myocardial ischemia/reperfusion injury in streptozotocin-induced diabetic rats. Mol Biol Rep., 2011; 38(7): 4327-4335.

45. Liu Z, Li W, Li X, Zhang M, Chen L, Zheng YN, Sun GZ, Ruan CC, Antidiabetic effects of malonyl ginsenosides from Panax ginseng on type 2 diabetic rats induced by high-fat diet and streptozotocin. J Ethnopharmacol., 2013; 145(1): 233-240.

46. Kochkin DV, Kachala VV, Shashkov AS, Chizhov AO, Chirva VY, Nosov AM, Malonyl-ginsenoside content of cell-suspension culture of Panax japonicus var. repens. Phytochemistry, 2013; 93: 18-26.

47. Cheng YJ, Zhang M, Liang QL, Hu P, Wang YM, Jun FW, Luo GA, Two-step preparation of ginsenoside- $\mathrm{Re}, \mathrm{Rb}_{1}$, $\mathrm{Rc}$ and $\mathrm{Rb}_{2}$ from the root of Panax ginseng by high-performance countercurrent chromatography. Separation and Purification Technology, 2011; 77: 347-354.

48. Court WA, Hendel JG, Elmi J, Reversed-phase high performance liquid chromatographic determination of ginsenosides of Panax quinque folium. J Chromatogr., 1996; 755: 11-17.

49. Liu Z, Wang CZ, Zhu XY, Wan JY, Zhang J, Li W, Ruan CC, Yuan CS, Dynamic changes in Neutral and Acidic ginsenosides with different cultivation ages and harvest seasons: identification of chemical characteristics for Panax ginseng quality control. Molecules, 2017; 22(5): 1-15. 